\title{
Working-Class Literature and/or Proletarian Literature: Polemics of the Russian and Soviet Literary Left
}

Katerina Clark

What did working-class literature mean in the Russian, and especially the Soviet, context? Actually, in the pre-revolutionary years when working-class literature first began to be published on any scale, but most particularly during the Soviet period, literature produced by, or about, the working classes was standardly referred to not as "working class" but rather as "proletarian literature" [proletarskaia literature]. This is an important distinction because in Bolshevik parlance the term "proletarian" had two main meanings: either of or by the working classes, or of or by the vanguard of the proletariat, i.e. of the Russian-cum-Soviet Communist Party. The latter definition dominated throughout the Soviet period, although in the first decades there was a significant lobby of writers who were fierce proponents of a "working-class literature" in the sense of a literature of and about the working classes-and so not necessarily by or about members of the Party.

In Marxist-Leninist writings any "proletarian" was ideally, or at least in his or her sympathies, not only a Party member but also working class. Hence, as if to smooth over the disparity between "proletarian" (as of the Party) and "proletarian" (as of the workers), most of the heroes of the classic novels of Soviet literature were workers (or poor peasants) or at least of working class origins. Their roles as workers and as Party members intertwined, although greater stress was laid on their roles in the Party than as workers. In the pre-revolutionary period, however, proletarian literature tended to be a literature about the working classes tout

How to cite this book chapter:

Clark, K. 20I7. Working-Class Literature and/or Proletarian Literature: Polemics of the Russian and Soviet Literary Left. In: Lennon, J. and Nilsson, M. (eds.) Working-Class Literature(s): Historical and International Perspectives. Pp. I-30. Stockholm: Stockholm University Press. DOI: https://doi.org/ I0.I6993/bam.b. License: CC-BY 
court. Much of it was written by actual workers about their lives and there was a common belief that it should be independently generated from within their ranks. During the Soviet years, there was a further complication-the interpretation of who could be included under the rubric "proletarian" shifted over time. At times, in addition to Party members and factory workers, those of poor peasant origin or agricultural laborers were viewed as "proletarians." At other times, one had to be a factory or construction worker to qualify.

This article focuses on industrial workers rather than agricultural laborers and follows "proletarian literature" from its beginnings in the 1890 s through the demise of the Soviet Union a century later. Given the complexity of the topic, I have divided the text into several sub-sections, each of which discusses a particular phase or aspect of the interpretation and practice of "proletarian literature" in relation to its treatment of workers.

The article reviews successive trends in the representation of proletarians and proletarian writers as they are related to representations of intellectuals. The tension between the educated intellectual and the proletarian (whether a worker or a Party member) was already an important issue in the pre-revolutionary period but became an obsession of Soviet literature. Many questions associated with the issue were debated, directly or indirectly, in the literature and criticism of these years. The questions included: Should proletarians learn from the better educated professional intellectuals or were they too tainted by their bourgeois class identities? Could intellectuals, indeed, ever be integrated into, or play a positive role in, proletarian culture? Or rather, should the proletariat generate its own intelligentsia from within-as Gramsci in his Prison Notebooks advocated for with the development of an "organic intelligentsia" which might assume hegemony-and a penetration throughout society of their own system of values and beliefs that would counteract bourgeois intellectual hegemony? Did all men have the capacity to function as intellectuals and writers, and how could workers, especially the predominantly illiterate or semi-literate workers of imperial Russia, be enabled to create their own literature, to express themselves? In the Soviet period especially, the ultimate question was What was, or should be, the relationship to each other of workers, intellectuals and the Party? 


\section{Working-Class Literature of the Pre-Revolutionary Years}

In the late decades of tsarism - from approximately the I890s until the Revolution in I9I7 - there emerged a working-class literature in the sense of a literature by workers and about their lives. Even though the Russian working classes were heavily illiterate, many workers, often self-taught, produced poems, fiction and other works during these years, some of which were published in trade union, Bolshevik or specialized papers and journals (Volkov, I95I). Between I905 and I9I3 almost every issue of a trade union or socialist party newspaper included at least a couple of poems by self-identified workers. There were also several publishing ventures that targeted the poorly educated, such as Gazeta-kopeika [the penny newspaper]. Additionally, concerned or idealistic Bolsheviks and leftists of assorted stripes acted as patrons to the worker writers and collectors of their literary efforts (Steinberg, 2002).

In the early twentieth century, the leading player and patron of this movement for a literature of the masses was Maxim Gorky, himself of lower-class background and self-educated but by then a famous writer. Gorky played an influential role in fostering a literature of the "self-taught writers," partly though his association with the publishing venture Znanie. Znanie operated from I 898 to I9I 3 and Gorky joined its editorial board in I900, becoming its leader in I902. Under Gorky's leadership Znanie began, in addition to publishing established authors who were disaffected by tsarism, to provide an outlet for a rising generation of young lower class authors. But even after he severed his ties with the publishing house in I 1 I 2 , he continued to act as a broker for lower class writers. However, post-I9I2, he increasingly differentiated between different categories of lower class writer, singling out proletarian writers in particular, and shepherding into print, for example, a series of anthologies of writings by "proletarian writers": Nashi pesni (I9I3), Pervyi proletarskii sbornik (I9I4) and Proletarskii sbornik (I9I7). Gorky also wrote (while residing temporarily in the U.S. in I906) The Mother (Mat'), a novel about factory workers who become revolutionaries. The novel is loosely based on actual incidents in Sormovo in I902. Its two main characters are a mother and her son, both impoverished factory workers. The son 
seems set on a life of dissolution and drunkenness, until he comes into contact with revolutionaries. And, since the text is by Gorky who would soon start the Capri school, the son starts reading the books they give him. His illiterate mother is, in turn, attracted to the revolutionary cause, though less by reading than by a profound love for her son. At the end of the novel, she dies a martyr's death: She picks up the party banner from a fallen comrade during a demonstration and is mowed down. This novel was to become a model for socialist realism (see below), where the political education and development of the "positive hero" provided a given novel's overarching plot structure.

Gorky was not only a firm believer in educating workers. He also contended that the uneducated workers should be encouraged to speak for themselves and acted as a patron for the self-taught, neophyte writers. In his article "On Self-Educated Writers" [O pisateliakh-samouchkakh] (I9II), he reports between I906 and I9IO that he received over 400 manuscripts from what he called "writers from the masses." In these relatively early years "proletarian literature" was virtually not yet a separate category and less than half of the manuscripts were from industrial workers. Given these writers' low level of education, most of their products were relatively primitive, abounding in grammatical errors and with little sense of how to construct a literary work. But to Gorky, this was not the point. "Please remember," he enjoined the readers of the article, "that I am talking not of talented people, not of art, but of the truth, about life, and above all about those who are capable of action, upbeat and can love what is eternally alive and all that is growing and noble - human" (Gor'kii, I9II). The workers were for their part passionate about the need to express themselves. As one worker from a train depot Gorky cites in the article puts it: "I would like to learn a little more ( $p o d$ "uchit'sia), so that what has stored up in my soul could flow out freely in words, and these words of mine and thoughts and feelings would be read by those around me....," while another writer, a metal worker who was self-educated, reported that "some unknown force is making me turn to writing."

Gorky's work in helping the downtrodden and marginal find their "voice" may have been in part influenced by, or was at least 
parallel to, a comparable movement in the United States for having workers (and other marginalized figures) write the stories of their lives, or at least relate them to ghost writers. By giving the downtrodden a "voice," it was felt, they might acquire full status in society. In America, this movement was centered around the journal The Independent, which, between 1902 and I906, published some 75 autobiographies of workers, immigrants, blacks, and native Americans. The journal's idealist editor, Hamilton Holt, setting great store by the enterprise, was moved to declare that "the history of the world is essentially the history of the coming into their own of the common people" (Holt, I906; as cited in Stein and Taft, I97I). In keeping with the consequent need to ensure that the stories were authentic, each of them was, whenever possible, written by its narrator or, in the case of those unable or too impatient to write, set down from interviews and then read and approved by the person telling his or her life story. In I906, the year Gorky visited America, Holt published The Life Stories of Americans as Told by Themselves, which selected sixteen "lifelets" from those that appeared in The Independent and, it is speculated, further reinforced Gorky's conviction that the underclass must be helped to write their own story.

"The coming into their own of the common people" was a cause Gorky was fervently committed to. While in exile on Capri he and other Party leaders, such as Alexander Bogdanov and Anatoly Lunacharsky, established a school for workers at his house that was set up to educate future leaders of the revolutionary movement, in order to make it possible for workers to play greater roles in the leadership of the Party (it ran from I909-I910); Gorky lectured there on Russian literature. The Capri teachers lamented the absence of "conscious leaders" among the workers in the Party and claimed this was because the Bolsheviks had not adequately addressed their intellectual development. Lenin was opposed to the school because he saw it as too independent of Party leadership, and indeed while there, Gorky and his associates developed a new concept for communists, Godbuilding [bogostroitel'stvo], which sought to recapture the power of myth for the revolution and to create a religious atheism that would elicit all the passion and sense of wonderment of religion but replace religion's god 
figure with man (collective humanity). Godbuilding was ridiculed by Lenin, who was also not an advocate of workerist literature. Rather, he insisted that Bolshevik intellectuals should inculcate political enlightenment in the proletarians and contended that a cogent revolutionary program could never emerge from a narrow worker milieu where their mental world was limited to everyday experiences.

Gorky, however, retained a faith in the capacities of the lower classes - especially workers (he was somewhat dismissive of peasants). He even asserted, in concluding his article on self-taught writers, that "precisely today, after [the revolution of] I905, the intellectual should look to the growth of new ideas, new forces among the masses." To him the most significant finding in the writings of the uneducated masses he received was a marked "negative attitude towards the intelligentsia" and "skepticism and mistrust" among the lower classes, regardless of their political orientation. Often, he reported, this attitude takes the form of rabid hostility and anger. In general, writers from the masses depict the intellectual as "a sort of gentleman who is used to giving orders" and lashing out violently at the downtrodden, while also being "weak-willed and always ill-acquainted with reality and a coward in moments of danger." These reported attitudes largely coincide with Gorky's own. He himself shared some of their prejudices against elite intellectuals, though he tended to articulate them in terms of movements in the literary world. Particular bêtes noirs for him were modernist and decadent writers (even Dostoevsky fell into this category for him). In this article, he remarks that "If one were to contrast their [lower class] hard lives and their cheerful voices with the hysterical, capricious maneuvers of established literati ... one would understand the hostile attitude of the masses to the intellectuals."

After the failure of the 1905 revolution in Russia, many advocated promoting a literature of the workers specifically, rather than of the broader category of the masses or the downtrodden. "Proletarian literature" became their banner term. Worker suspicion of educated elites became more pronounced and many writers wanted to throw off any tutelage from them (sometimes including from the Capri school). They expressed skepticism that 
intellectuals could ever fully express a truly working class point of view, commonly alleging that intellectuals could write about workers but could never really feel as workers do. The caricatured image of the "bourgeois" intellectual lingered throughout the Soviet period and reappeared in several examples of Soviet literature, as we shall see. But, in the meantime, many working-class writers advocated forming a fully independent literary movement, to be headed by truly proletarian intellectuals. The opposition to "bourgeois" intellectuals came not only because of their condescending, paternalistic attitudes, but also because supporters of a genuinely working-class literature had begun to aspire for it to be more than a niche literature. They often sought its hegemony as "proletarian literature."

\section{The Early Soviet years}

The polemics surrounding the issue of what was "proletarian literature," who could be considered a proletarian writer, and the jostling for dominance among contending claimants to the title "leader of proletarian literature" continued well after the Revolution of I9I7 and the institution of Soviet power. In the "workers state," however, the stakes had become higher and debates on the meaning of proletarian literature only intensified. During the I920s the different positions in the arguments were espoused by different Party leaders and also by different and new, self-styled "proletarian" literary associations. The polemics continued for the entire decade until they were more or less ended by the formation of the Writers Union in I932.

The first major Soviet organization for "proletarian literature" was the Proletcult (Proletarian Culture or Proletarskaia kul'tura), founded on I6 October I9I7, one week before the Bolsheviks took power - an indication in itself of the way I9I7 was no absolute dividing line in the story of Soviet proletarian literature. It was founded when nearly 200 representatives of workers' cultural-enlightenment societies, including the Capri veterans, trade union and factory committees, and members of assorted parties of the left attended the meeting in Petrograd, which aimed to establish a new cultural organization for workers. With support of the 
Bolsheviks, the Proletcult developed into a national organization, though it was extremely variegated in its membership and their aesthetic orientations and so never really comprised a coherent movement (Malley, I990). In the post-revolutionary years, the Proletcult was the only major cultural organization prepared to assert that literature should be working class without necessarily being Party-minded (Brodskii et al., I929).

In this early phase of Soviet proletarian literature, most of the texts published as "proletarian" were poetry, as was also true of the pre-revolutionary movement. Of the 429 texts that the "selftaught" writers sent to Gorky between I906 and I9I0, only 67 were stories or plays, the rest were poems (Gorky, I9I I). Many of the poems of the early post-revolutionary period were marked by a utopian universalism (sometimes called "Cosmism"). In this era of revolutionary fervor the hyperbolic and ecstatic were in vogue, but also a key theme was identifying the worker with the machines and metals he worked with. As Vladimir Kirillov wrote in I9 8 , "We have grown close to metal and fused our souls with machines." In a much-anthologized poem, "We grow out of iron" ["My rastem iz zheleza"], another prominent proletarian writer, Alexei Gastev, wrote of the revolutionary poet as developing into a mythic giant, reaching the height of smokestacks, as iron blood flows into his veins-in effect challenging the effete bourgeois poet who did not have such privileged access to metals or machines. The worker poets were self-declaredly trading the effete eloquence of the educated bourgeois for directness, virility, power and the toughness of metals. As one literary critic described it in the Petrograd Proletcult journal Griadushchee [The Future], in contemporary Russian literature two class perspectives were in conflict: the antiquated bourgeois "poetry of gold and ornament" and the new proletarian "poetry of iron" (Bogdat'eva, I9I8, as cited in Steinberg, 2002).

Despite such bombastic rhetoric in its poetry, many leaders of Proletcult, such as Bogdanov, came from elite educated backgrounds, which partly contributed to the movement eventually losing favor. By I920, it was no longer a major presence in Soviet Russia. By then, new proletarian literary organizations, which favored prose rather than poetry, were emerging. Initially, the most 
important of them was Smithy [Kuznitsa], which was formed from a group of writers that broke away from Proletcult on February I of that year on the grounds that it was too dominated by nonproletarians and hampering the development of a proletarian literature. That May, the group began a journal, Smithy, after which the breakaway group then came to be known. In October of the same year, the First Congress of Proletarian Writers was held in Moscow and established a new body that was to assume great importance in the literary history of the I920s: the All-Russian Union of Proletarian Writers (VSPP), later renamed the Association (VAPP).

Among groups advocating a proletarian literature, the great division between those who believed it should be by or of the working classes and those who believed it should be by or of the Party was becoming exacerbated. In I922, a new proletarian writers' organization, October [Oktiabr'] was formed of militant Party members, both the first and the main such body to agitate for Party commitment as the first principle of Soviet literature (Oktiabr', I922). Shortly thereafter, October gained control of a new literary polemical journal On Guard [Na postu] (I923-25), which became conspicuous for its attacks on rivals-a category which included not only so-called fellow travelers [poputchiki] but also writers of Smithy who were branded unproletarian for their failure to insist on a Party orientation in literature. The group lacked strong support from Soviet officialdom, however, and had trouble getting funding for the journal which was closed in I925. Nonetheless, it was restarted as On Literary Guard [Na literaturnom postu] in 1927 , by which time the group had become the most powerful and most feared in Soviet literature. They had assumed the leadership of first MAPP (the Moscow branch of VAPP) and enjoyed such an overwhelming control of RAPP (the Russian sector of it) that they came to be known as RAPP.

Though the two groups (Smithy and RAPP) were the chief, rival claimants to the title "proletarian literature," almost none of the leaders of either organization were, in fact, of a working-class background. Most of the prominent writers in Smithy were of peasant or petty bourgeois origins (as was also true of most Proletcult writers), while the main writers in RAPP were characteristically from the provinces and of petty bourgeois origins. 
In both cases, the writers tended to have a background in Soviet journalism before becoming writers, though many of the writers in Smithy had also contributed to pre-revolutionary proletarian literature (Clark, 2000). Thus, their claim to represent proletarians was somewhat tenuous, though less problematical for the RAPPists, since they identified "proletarian" with "the vanguard of the proletariat," i.e. the Party. Smithy urged proletarian writers to become Party-minded, but this was not considered a sine qua non, as it was on the RAPP platform, nor was it as prominent in the Smithy platform as the demand that all Soviet literature be of the working classes. Many members of Smithy were not in the Party though its most famous writer, Fedor Gladkov, joined the Party in I920.

Both groups were, in their writings of the I920s, obsessed with the question of what were the respective roles of intellectuals, Party officials, and workers in the new Soviet society. Their positions largely echo those of pre-revolutionary debates on proletarian literature, except that now, of course, the Party had to be a factor in any formulation. Smithy members largely insisted on an authentically working-class hero, while RAPP writers appropriated that topos for Party members; in their fiction no intellectual could feel at home in the Party.

The contrast between the Smithy and RAPP conceptions of the role of the proletarian can be seen in a comparison of two works: A Week (Nedelia, I922) by Iurii Libedinskii who was to function in the second half of the I920s as the leading theoretician of RAPP, and Cement (Tsement, I925) by Fedor Gladkov, a leader of Smithy. Many of the differences between Libedinskii's and Gladkov's fiction that are relevant here can be attributed to the two writers' different orientations within proletarian literature. Libedinskii's first story, “A Week," was hailed repeatedly (at the time) as the first "successful" or "realistic" work of proletarian literature (Gorbachev, I928). Set in the Party administration of a Siberian town during the Civil War, it shows an obsessive preoccupation with the question of how (or whether) a person of education or intellectual interests could (or should) be incorporated into the Party, or into the institutions of Bolshevik society. As the story progresses, it soon becomes clear that the author is 
judging his characters according to whether they are capable of spontaneous and, therefore, reliable attachment to the Party. The Party is described as a "family" whose members have a sense of belonging to one another (Libekinskii, I922). This bond is the "proletarian point of view" and their commitment to its purposes. The proletarian Bolsheviks report that their espousal of this point of view comes from feeling rather than from reason, that it is natural to them (Ibid.). By contrast, those Bolsheviks who have an intellectual mindset appear as wanting, through rational conviction, to join the family, but destined to remain outsiders in it. The Party ethos and gut sense of belonging simply do not come naturally to them, and they are torn by inner conflicts. In a critical moment during a counterrevolutionary raid, the main example of the intellectual, Martynov, hesitates before pulling the trigger. In other words, he is depicted as "weak-willed and a coward in the face of danger," in the same way that Gorky reported of the way bourgeois intellectuals were often represented in the pre-revolutionary writings of the masses.

Gladkov's Cement is one of the two main and most popular exemplars of socialist realism, the other being Nikolai Ostrovsky's How the Steel Was Tempered (Not coincidentally, Ostrovsky's novel is also about the Civil War. However, unlike Gladkov's novel, the protagonist primarily identifies himself as a Civil War hero and not with his working-class origins). Cement's plot concerns the restoration of a pre-revolutionary factory in a provincial town as the Civil War is winding down, amidst trying conditions of food and fuel shortages, periodic raids by White Guards, and general chaos. In other words, the situation is comparable to that of A Week, except that, appropriately enough, the center of action is the factory itself, not the Party headquarters. Furthermore, the main protagonist (and hero), Gleb Chumalov, is portrayed as being a worker above all. Although it is also true that Gleb is a Party member, and, indeed, is made head of the factory's Party committee shortly after the action of the novel commences, the essential image of him projected in the novel is of a young worker. Moreover, the restoration of the factory to efficient production came about not by the dutiful execution of Party directives but rather as Gleb stood up to his superiors. The mandate for this 
disregard for authority comes from Gleb being identified not only as a worker but also as a returning hero from the Civil War. The sorts of qualities which ensured his success in war now define his actions at the factory.

Gleb represents a new and dynamic kind of hero. $\mathrm{He}-$ as became true of most heroes from I930's fiction-is all "struggle," "vigilance," heroic achievement, energy, and another cluster of qualities similar to the "true grit" of the American frontier: "stickability" [vyderzhka], "hard as flint" [kremen'], and "will" [volia]. The worker, then, was now a man of action, virile like the man of iron from early post-revolutionary poetry and like the workers of that poetry presented in hyperbolic terms. And yet, Gleb was identified less with the machine than with the bogatyr', the mythical knight of the Russian folk tradition now grafted onto a narrative of production. Ostensibly, Cement is a novel about postwar reconstruction and has as its subjects problems of supply, administration, labor relations, technology and guerilla insurgency on the part of counterrevolutionaries. Gleb charges over the novel's world with the greatest of ease, taking on all manner of fierce, unremitting obstacles, each one of which he manages to overcome with amazing dispatch. One admiring onlooker remarks as he watches Gleb set every corner of the economy in motion with his incredible energy: "Dammit, Chumalov old man! Harness yourself to the factory instead of the dynamos, and you'll be able to make it work all by yourself" (Gladkov, I925, 53).

Despite this apparent privileging of the new man over technology, Cement contains a scene of what could be called 'the industrial sublime,' as Gleb visits his factory's gleaming machine. As in countless other Soviet - and especially Stalinist texts-the hero is overwhelmed when he comes across the colossus of a new construction site or, as here, part of a factory (the machine room, a veritable proletarian cathedral). The novel also draws on common tropes for representing the intellectual (in contrast to the worker) that were common in pre-revolutionary working-class literature. The main example of the intellectual in this text is Sergei, the dedicated Party member from the educated bourgeoisie. His father inhabits a clichéd musty world of books and is cut off from the real world, while Sergei, in a virtual illustration of a point made 
by Gramsci, displays great eloquence when addressing the workers. The workers, however, soon lose interest in his speech while Gleb, though poor in words, speaks with passion and rouses them for the cause. Similarly, when, in the novel's final scene at the celebration of the factory's reopening, Gleb, is called upon to speak, he feels that words are inadequate to express the moment. And yet, when he does address the gathered crowd, his words are met by a thunder of applause. Ultimately, Sergei, for all his devotion to the Party and self-sacrifice, has to recognize that he is alien in the Party and accept being purged from it, despite his devastation.

However, in the works of these years, the militantly "proletarian" stance of both Smithy and RAPP writers was effectively mitigated by the Leninist doctrine of the "spets" (i.e. the specialist or in other words the professionally educated expert). Lenin directed that, though such figures were from the bourgeoisie, their expertise was essential at a time when the country was seeking to establish itself. He decided that they should not be persecuted, but rather encouraged to accept Soviet power and work for it. Consequently, though Libedinskii in his articles insisted that only someone with the "proletarian point of view" should be able to take part in the creation of Soviet literature, he allowed that those who did not have it could acquire it in the process of class struggle (Libedinskii, I924). In "A Week" specifically and in proletarian literature of this period generally, the fact that a given protagonist possessed a bourgeois education is represented as a reason for caution, but not for outright rejection. For instance, in Cement, the issue of the spec is largely tackled through another character, the engineer Kleist, who (like Sergei) is from the bourgeois intelligentsia. The story of Kleist provides a version of the narrative of the spets. Initially, Kleist is a far more sinister figure than Sergei; far from being a Party member, he had been a counterrevolutionary and, like Sergei's father, shuts himself away in an isolated world. But Kleist (in effect obeying the doctrine of the spec) has to learn to rein in his class hatred and work with the engineer. Ultimately, Kleist is moved to dedicate himself to the cause of reconstruction and Soviet power.

By no means were all of the Party leadership in favor of a proletarian literature. Lenin, especially in his 1905 essay "Party 
Organization and Party Literature," insisted that there could be no independent literature and that all writers should essentially subordinate themselves to the policies and needs of the party so that literature would become "a cog or a screw" in the great Party effort. And Trotsky, especially in a series of essays he published in Pravda during the early I920s and later put together as Literature and Revolution [Literatura $i$ revoliutsiia] (I925), argued that the workers were as yet not sufficiently educated to generate a quality literature of their own and that consequently (during the interim while they gained more education and culture) so-called fellow-travelers should be the mainstay of Soviet literature. In effect, the Soviet Union would bypass proletarian literature and aim to develop a single "socialist" literature and culture.

But then Lenin died in I 924 and Trotsky lost out in the struggle for leadership. In October I927, he was expelled from the Central Committee and in November from the Party. His supporters were expelled that December, and he was exiled in r929. The demise of Trotsky meant the closing down or shake-up of the leading publishing houses and journals where he had acted as patron and which promoted fellow-traveler writers. In consequence, the stakes of RAPP, hitherto the chief opponent of fellow-traveler literature, rose. By I928, it was fairly apparent that the Party favored the institution of a proletarian literature in the Soviet Union and that it had in mind primarily Party-oriented literature. ${ }^{\mathrm{I}}$ RAPP became extremely powerful and was well positioned to lead a proposed cultural revolution.

\section{Literature of the First Five-Year Plan}

In I928, the First Five Year Plan was launched, which constituted an ambitious program for large-scale industrialization and collectivization to be accompanied by a cultural revolution. The leadership aimed not only to modernize but also to eliminate the tensions between the workers and the bourgeoisie by privileging workers. "Proletarianization" became a centerpiece of the Party platform. Bourgeois professionals were replaced by proletarians (whether working class or from the Party) on a huge scale. In literature, the professional writer was denigrated and expected to 
compensate for having the wrong class identity by subordinating him or herself to the economic cause and its main actors: the worker masses. In a reversal of status within culture, workers were to become writers, and writers were to attempt to merge with the working classes. In ways similar to what Walter Benjamin has outlined in "The Author as Producer" (itself heavily influenced by the cultural ethos of the Soviet First Five-Year Plan), the image of the writer as a genius-creator was debunked, and the producer was to be the author for the new age. A great deal of effort in the literary world was put into having workers write about their own work place experiences. As for professional Soviet writers, they were to be auxiliaries to this cause and so were organized in "brigades" and sent to the main construction and production sites to enjoy such service roles as tutoring the workers in writing, and organizing the enterprise's wall newspaper or its library.

RAPP played the leading role in organizing the worker literary effort in the plan years. It encouraged workers, particularly record setting workers [udarniki], to write about their achievements at work for the benefit of others. ${ }^{2}$ The resulting literature, largely comprising "sketches" [ocherki], tended to be highly journalistic and to provide a wealth of detail about technical aspects of a production process and how the worker-author's workplace was organized. In other words, this literature, though more literally working class, was somewhat pedestrian by comparison with the fiction of Gladkov, which was so much more colorful, action-packed and hyperbolic in style. Several writers sought to atone for their sin of not being purely working class and spent extended time on the new construction sites and giant factories. Some major novels were generated from their experiences, such as Gladkov's Energy, also known as Power [Energiia] (1932-38), based on his time in the gigantic construction project, Dneprostroi, in southeast Ukraine; Marietta Shaginian's HydroCentral [Gidrotsentral] (I929), set in the Dzorages' hydroelectric dam in her native Armenia; and Valentin Kataev's Time, Forward! [Vremia, Vpered!] (I933), set in Magnitostroi a new industrial complex being built just beyond the Urals.

Kataev's fast-paced and suspenseful Time, Forward! is the most successful and most readable of all the plan-years' fiction. 
It concerns a team of concrete workers at Magnitostroi who are trying to break the national record for how much concrete was poured in one shift. The emphasis, then, is on pace. The ever quickening pace of the concrete workers is matched by the ever quickening pace with which the very landscape around them is transformed. The hero finds that the terrain changes so radically every day that he keeps having to rechart his route to work (Kataev, I932).

\section{"The History of the Factories" as a Factory of History}

Gorky returned to the Soviet Union permanently in I930 and continued-now on an enhanced scale-his pre-revolutionary work helping the untutored masses become competent writers. To this end he founded the journal Literary Study [Literaturnaia ucheba] in I930 to give advice to beginner writers; many of those associated with the journal subsequently became important names in Soviet literature (Dobrenko, I997).

Gorky also devoted a lot of attention to having workers write about their own experiences in the workplace. The masses were to be allegedly transformed by writing their own lives. In the first half of the I930s, this attempt at "writing Soviet man" was focused on two series of monographs, both founded in I93 I on order of the Central Committee of the Party but also primarily on Gorky's initiative. The first of these was "The History of the Civil War," founded on July 30. The second, one of Gorky's pet ventures and our main concern here, was "The History of the Factories" [Istoriia fabrik i zavodov, or Istoriia zavodov] established by decree of October I93 I.

In the American I930s, especially under the New Deal, the government sponsored the writing of life stories by workers and other ordinary Americans (Denning, I996). ${ }^{3}$ However , “The History of the Factories" was a more ambitious undertaking. The idea was to have each major factory write its own history. These histories were to be collectively written but largely comprised of individual autobiographical accounts by workers of their time at the given factory or construction site. All the members of a given factory were to be potentially involved in writing them. In so doing, they 
were to draw on the memoirs of old workers from the factory, especially of Old Bolsheviks, on archival material, and on approved, Marxist accounts of history, as well. In the first instance, IO2 of the country's largest enterprises were involved (primarily in the Russian Republic and Ukraine). Later, 200 more were added, but it was an aim to have a department for "The History of the Factories" in every major factory. In the heyday of this scheme between I932 and I935, as many as 88 journalists and writers worked full-time on it, in addition to others co-opted on a part-time basis. The yield in actual books was not so high. By the Second World War, over twenty books had been published in the series, and factories that did not manage a book generally produced more modest publications of some sort (Bachilo, I959).

These histories were not only to be about factories, literally, but also about railways, the metro, canals and other such construction projects. The "factory" was to be the site of radical transformation. At the center of all these histories-whether of new factories and construction sites or those of prerevolutionary Russia-had to be the absolute contrast between the $\mathrm{BC}$ of prerevolutionary Russia and the $\mathrm{AD}$ of the enterprise under the Bolsheviks, typically described as going from an era of "rapacious barbarism," in which "everywhere one found backwardness and ignorance... the unenlightened poor and the downtrodden," to a situation where it could be said of the workers that, whatever their position in the factory, labor had become for them "creative, rich in meaning, and joyous" (Gorky and Mirskii, I935). In other words, the temporal dimension, which was not very marked in the largely presentist accounts of workers' lives written during the years of the First Five-Year Plan, was central.

The project's main purpose was to reinforce or even create a particular consciousness, both in those who wrote and in their readers. It was not so much a working-class consciousness but rather a Bolshevik one. Gorky, in a much-quoted remark, called the project "a special kind of communist university [Komvuz]" offering a "process of Leninist study" ("Uskorit", I932). The factory, then, was no longer just the site for the production of material goods. Its primary function was as a site for the production of subjects. In this aspect the factory was not self-sufficient, as it 
might have seemed to be in the immediately preceding, proletarian phase of Soviet culture during the First Five-Year Plan. Production of material goods, such as pouring concrete in Valentin Kataev's Time, Forward! was no longer an end in itself.

Gorky in his comments on the project always insisted that the worker must "speak for himself" as a necessary condition in "the working class's striving for self-consciousness" (I93 I). But in reality that was far from the case. The many accounts of the organization of the project, especially in its own organ-the journal Istoriia zavodov-give the distinct impression that it was largely directed by the Party, on the one hand, and by professional writers who were assigned to particular enterprises, on the other. ${ }^{4}$ Additionally, in an effort to ensure that the workers' recollections fit the desired narrative, not only were they assigned specific texts to read but also a number of state and Party bodies that dealt with ideology were sent to help the factories and their workers with the histories: Party organizations, the Komsomol, Istpart (a body that oversaw the history of the Party), the Trade Unions, the Communist Academy, the Academy of Sciences, and the management and Party heads of individual factories and construction projects ("Sozdadim", I933). Also, questionnaires were distributed to the workers in advance, as a way of generating brief, standardized outlines of individual workers' careers. Those responsible for collecting oral narratives were advised that they should in no way record them directly (Nishchinskii, I933; Rabinovich, I933). Moreover, once the ostensibly "own stories" of workers were collected, they were subjected to a "working over" by professional writers, sometimes to repeated workings over.

In "The History of the Factories," then, the workers' autobiographies were presented as the spontaneous outpourings of poorly educated individuals. The distinction between third-person and first-person narration (never an absolute one) was particularly blurred, as was the line between self-expression and boiler-plate narrative. One egregious example occurred when a small team of professional writers were charged with putting together the final version of The White-Sea Baltic Canal [Belomorsko-Baltiiskii kanal imeni Stalina]. Set in an infamous forced-labor camp, these writers began interpolating "bits" of one individual worker's 
narrative into another's to streamline the book. Hence, many of the (auto)biographies presented in the book were actually composites of different narratives. In seeking to make the shifts from a "bit" of one worker's biography to a "bit" of another's the formalist, Victor Shklovsky, a member of the team, came up with a system of three varieties of "montage" to be used (Gauzner, I934).

"The History of the Factories" was that privileged department of each factory, which was designated to manufacture texts rather than goods, a higher-order process. But even as the texts would be perfected in the constant "working over," so too would be the worker author-readers, so that, in this process, they too would approach becoming perfect texts. They could become higher-order selves once they had inscribed themselves/been inscribed into the (auto)biographical narratives. Thus, the question has to be asked: "Who writes whom?" Are the workers merely written, or do they discover the capacity to write and, through writing, inscribe themselves into the national narrative with a reinforced working-class identity?

\section{Socialist Realism}

A year after "The History of the Factories" project was launched Soviet literature underwent a profound change. By Central Committee decree of 23 April 1932, all independent writers' organizations were abolished and all Soviet writers were to join a single body: the Union of Soviet Writers. Gorky was made its titular head. The list of organizations to be eliminated surprisingly included the proletarian organization, RAPP, which had as recently as I93 I seemed to enjoy so much favor with the Party that there was a distinct danger all literary organizations would be subsumed under it. A month later, in May I932, a new term, socialist realism, was coined as the "method," or theory for a mandated unified approach to the writing of literature. The term proletarian had been largely replaced in Bolshevik rhetoric by "socialist." In other words, there is a real question as to whether socialist realist literature, even if by workers or about workers, could be considered "working class."

As I have argued in The Soviet Novel: History as Ritual, what the new term came to mean in practice was that literature and in 
particular the novel, or principal genre of socialist realism, was organized by a de facto masterplot that charted the "positive" hero's progress to a high level of political consciousness. The novel was then ritualized, as were in effect most of the "autobiographies" in "The History of the Factories" series, although the standard outline of a worker's life in works from that series - from ignorance and exploitation in the pre-revolutionary factory to education, greater consciousness and a superior workplace in the Soviet period - was a little different from the standard trajectory of the Soviet novel. The principal difference derived from the fact that in the standard socialist realist novel the Party and the Party hierarchy played a dominant role; a given novel's "positive hero" occupied a clear position on this hierarchy and moved up it in tandem with his political development. "Proletarian" now meant that any worker-hero was most likely a Party member and his development over the course of the novel generally led to his promotion within the Party or local administration. Commonly, at the end of a novel, he assumed leadership in the microcosm of the Soviet society in which the novel was set in a factory, suburb, collective farm or region. This outcome generally coincides with the successful completion of a task in the economic sphere (over-fulfilling the plan, building a dam, etc.), and very likely with a resolution in the hero's private life as well (boy gets girl). In the course of his progression in political consciousness and self-mastery (to greater discipline), the positive hero is guided by someone superior in the Party hierarchy and, in The Soviet Novel, I have analyzed the process as a version of an initiation ritual with the older Party official as a mentor figure. In other words, while the worker in "The History of the Factories" revealed in his autobiographical account how he had achieved a greater degree of consciousness, the socialist realist positive hero achieved (allegorically) complete consciousness. Moreover, a mentor figure from the Party hierarchy is not a factor in these worker autobiographies and the "author" is rarely a Party member, so that they represent mutations of the pre-revolutionary workerist literature that likewise had Gorky as its patron. I might add that, although Cement is considered an alltime classic of socialist realism, it was really only embryonically so: Gleb's superiors in the Party, far from fulfilling the mentor 
function, have strong negative traits and are even his antagonists whom he must defy in order to have the factory restored. Furthermore, at the end of the novel, he is not promoted, and they remain in their positions. ${ }^{5}$

The masterplot is not my subject here, however, but rather the proletarian hero in a socialist realist novel. Several generalizations can be made. First, although a Party-guided political and behavioral progression provided the central arc of a standard socialist realist plot, a proletarian identity for the hero, or at least a poor peasant identity, was essential. Equally essential was some past of military engagement as revolutionary struggle. In the inter-war years, most literary heroes had fought for the Reds in the Soviet Civil War of I9I8-2I. After the Second World War, this criterion became less viable and a heroic record in the Second World War became de rigueur; ideally the hero would have fought from Stalingrad to Berlin' as virtual stations of the cross of Soviet mythology. The two - proletarian identity and military heroism were essentially twin criteria for positive hero status. For example, in Nikolai Ostrovsky's novel How the Steel Was Tempered [Kak zakalialas's stal'] (I932-34), a candidate for the status of the socialist realist novel, the hero Pavel Korchagin, was an indefatigable fighter in the Civil War whose grave injury and lifethreatening illness did not deter him for most of the novel. He was of working-class origins and had been a worker in a train depot before joining the Red Army.

An important distinction from the fiction of the First Five-Year Plan, however, was that in fully-fledged socialist realism, some proletarian status, such as working in a factory, was no longer enough for a socialist realist hero. Stalin had reversed the FiveYear-Plan tide of militant "proletarianization" with, inter alia, the slogan derived from his speech to the graduates from the Red Army Academies of 4 May 1935 "Cadres Decide Everything" [kadry reshaiut vse], i.e. qualified persons in command positions have priority. The positive heroes of the I93os fiction (and to a lesser extent of the I940s) follow the trajectory of the nation as a whole to greater education and even higher education. Most strikingly, many worker-heroes aspire to become engineers. They thirst for an education that ensures social mobility and essentially cross 
class lines, leaving their working-class lives behind as they become engineers and managers or showing greater reverence for intellectual activity than their I920s predecessors. In How the Steel Was Tempered, for example, Pavel Korchagin, far from feeling alienated from "the musty world of books," is shown as being drawn to books at a very early age. The humble worker borrows them from a bourgeois friend and, though he must eventually recognize that she is his class enemy in later years, he is guided by Party people in more directed reading and devours books in a frenetic attempt to educate himself. Throughout his military career, Pavel is inspired by Ethel Voynich's The Gadfly (I897), a novel about an Italian revolutionary from an upper-class background that was written by a similarly upper-class Englishwoman who was married to a Polish revolutionary. On the eve of a major battle, Pavel reads the book to a rapt audience of soldiers as an inspirational text.

We will recall here the slogan used at the First Writers Congress of I934: "Engineers of Human Souls." As a Literary Gazette [Literaturnaia gazeta] editorial published on the opening day of the Congress makes particularly clear (citing words attributed to Stalin), the model for the writer is now tied to the model for the engineer ("Segodnia", I934). Writers were no longer to overcome their tainted, bourgeois pasts and aspire to a working-class mentality, as during the First Five-Year Plan but were rather to lead and mold - construct - workers and peasants. This revalorization of the educated and professionally trained sometimes even led to someone of that category assuming a mentor role for the young worker rather than a senior member of the local Party hierarchy. One example of this would be Vasilii Grossman's novel Stepan Kol'chugin (1938). Set in a Donbass mining town, the novel chronicles the progress of its eponymous hero, somewhat along the lines of Gorky's socialist realist paradigm The Mother, from callow and oppressed working class lad to a conscious Bolshevik revolutionary. A major distinction, however, would be that, while the son, Pavel, in Mother is propelled onto his path to consciousness through contact with revolutionaries among his fellow workers, for Stepan, a major step forward on that path occurs when he is taken under the wing of a chemist who works at his factory's 
laboratory and instructs him, not in ideology, but in the natural sciences. Moreover, Stepan conceives the progress to communism in terms of building a city that is new, rationally organized, and monumentally proportioned (Grossman, I938). This shift from an emphasis on production of material goods to building a model city could be related to the great Stalinist project of the I930s. The project reconstructs Moscow as the nation's capital and emblem, but is also symptomatic of the way the emphasis on sheer output of material goods had characterized fiction of the plan years, or what Kataev was often attacked for as fetishization of production in a "concrete hysteria." "This emphasis was now often subordinated in literary texts to the output of a human product, as in "The History of the Factory" series. The reconstruction of Moscow was a project of great symbolic resonance and connected with the centralization of the country in a hierarchy of power, so that the shift of emphasis from the production of material goods to the creation of a new city also stood for fealty not to a proletarian identity so much as to the political status quo.

It should not be assumed that the shift to a mentor for the working-class hero from among specialist intellectuals was general in the literature of the I930s. More often, the mentor figure was the proletarian Bolshevik leader with or without professional training. But the Party organizer, among the various characters in a given work, most frequently functions as the "engineer" as the one most directly responsible for producing both the industrial complex or its material output and its new man. This is particularly the case in what is probably the most prominent socialist realist production novel of the I930s: Aleksandr Malyshkin's People of the Backwoods [Liudi iz zakholust'ia] (1938). At the core of People from the Backwoods is material Malyshkin gathered during trips he made to Magnitostroi in I93 I and I932, together with Valentin Kataev. Inasmuch as the material Kataev gathered there formed the basis for Time, Forward!, a comparison of the two novels helps highlight how the values of the early I930s contrast with those of the plan years. People from the Backwoods, having taken so long to write, straddles the plan years and the I930s. Consequently, it became a First-Five-Year Plan novel that has been largely influenced with the values of the 
Stalinist I930s. So while Kataev's novel is completely concerned with the protagonists on a particular construction site trying to break the national record for pouring concrete in one shift, Malyshkin's downplays the production aspect of Magnitostroi and shifts the focus of the action from the production site - the stroi - to the town-Magnitogorsk-which houses the workers. Moreover, Kataev attempts to provide a comprehensive account of the great changes taking place in 'the thirties,' his original title for the novel. Hence, he relates events in Magnitogorsk, not just to their local significance but to the situation of the country in agriculture, industry, politics, and intellectual life, no less.

The plot of People from the Backwoods is played out as a Manichaean drama wherein protagonists oscillate between identifying with the "backwoods" (chaos, ignorance, primitivism, a mercantilist mentality, and an interest in luxury and comfort - not to mention perfume, the foxtrot and the tango) and identifying with "Moscow" (Malyshkin, I956). Magnitogorsk itself represents an intermediate point in a tri-partite hierarchy of place. When a wavering soul is won for the light, however, it is not because he is captivated by the poetry of collective labor or because he gets a thrill as the first tractor comes of the assembly line, as tended to be the case in fiction of the First Five-Year Plan. In fiction of this period, such thrills are definitely downgraded inasmuch as they are now relegated to the province of women (such as, in People from the Backwoods, the erstwhile gadfly, whose principal identity is as an errant wife; mended her ways after an encounter with the almighty tractor). Instead, male heroes are now overwhelmed by gigantic construction projects and, above all, by the new socialist town. The most crucial conversion in Malyshkin's novel - that of the youngest protagonist, a former farm laborer - occurs when the Party organizer paints for him an enticing picture of the path he could take in life, culminating in his becoming an engineer. We sense, however, that the lad (Petr) is more likely destined to become a political leader than a designer of factories or machinery. (This development would have taken place in Part II which, due to Malyshkin's early death in I938, was never completed.) Another factory worker (Pashka), dreams of enrolling in a literary school, though he ultimately opts to join a new construction project (ibid.). 
The teleological structure of I 93 os socialist realist novels, then, charts not only political Bildung for workers and their personal maturation but also their social mobility. Though their young heroes do not want to stay in the working classes, they reject the educated intellectuals of the old dispensation who, as Malyshkin puts it, are "puffed up with their learning" and highly eloquent but live in the "half light," of a "spiritual backwoods" [dukhovnoe zakholust'e] cut off from the contemporary milieu. They read books by Nietzsche, Bergson and such émigré philosophers as Semyon Frank, Nikolai Berdiaev and Nikolai Lossky (ibid.). So while the young proletarian heroes aspire to an education, it is essentially to make them part of a new working-class intelligentsia, in order to supplant the rotten old one. Many of the attitudes expressed by the narrator and by "positive" protagonists are reminiscent of those to be found in Gladkov's Cement. For example, the great sacrifices made in the Civil War should serve as a model for workers in the present-day (ibid.). But a crucial difference between the representations of the workers in the two novels is found in the trajectory of social mobility through advanced education, which was outside the mental universe of Gleb in Cement.

In the post-war, late Stalin years, literature about industrial production or construction dispensed almost completely with worker-heroes and largely concerned clashes within the elite: state management, Party officialdom and engineers. Many of the central tropes of Gladkov's Cement were used (not entirely surprising given that between 1945 and 1948 he headed the Literary Institute that trained writers). In particular, the representation of the positive hero as a dynamo, or a ball of energy who pulls off the impossible in the workplace against the advice of professional engineers and diehard bureaucrats, reoccurs. And yet, there is an important distinction here, to be seen, for example, in Vasilii Azhaev's Stalinprize winning Far from Moscow (Daleko ot Moskvy, I948): the "impossible" feat pulled off in the workplace is no longer due to the initiative of a dedicated worker. Rather, it constitutes the main hero's insistence on placing him (or her) self within the political hierarchy, in which this feat must be pulled off, no matter the odds because that is what "Moscow" has ordered (and, of course, it is) (Azhaev, I948). 
In the literature of the "thaws" that came under Khrushchev after Stalin died in I953, pushing the pace of production is debunked as Stalinist excess. The conventional opposition-between the conscientious Party member of working-class origins and the engineer who effectively impedes the pace of progress with his timidity and rejects the worker's bold plan on the grounds that it is not feasible scientifically-was now inverted. Most of the main works that engage industrial themes feature scientists who have invented superior machines or theories, but are thwarted in getting them adopted by corrupt or "careerist" bureaucrats blocking their approval. This is the detriment of the common good. However, the inventor figures in this literature are no genial workers. On the contrary, in the most famous and incendiary of these texts, $\mathrm{V}$. Dudintsev's Not by Bread Alone [Ne kblebom edinym] (I956), the corrupt factory manager (nemesis of the hero-inventor) is a Party member of proletarian origins, while the inventor has a university degree. The only prominent author to champion the workers in these years, Vsevolod Kochetov, produced two major novels about dynasties of workers: The Zhurbins (Zhurbiny, I952) about shipbuilders and The Ershov Brothers [Brat'ia Ershovy] (1958) about metalworkers, written in response to Dudintsev's novel. Kochetov, though fiercely devoted to Party, proletariat (though not himself of worker origins), and somewhat xenophobic, was swimming against what was generally seen as a liberalizing tide. By the I980s Era of Perestroika, Dudintsev was publishing White Garments, or Raiments [Belye odezhdy] (1987), an exposé of the infamous agrobiologist, Trofim Lysenko, who challenged conventional wisdom in genetics with his claims that one could cultivate plants in such a way that they could thrive despite environmental factors like climate. In White Garments scientists from working class backgrounds are represented as usurpers, a complete reversal of the common Stalinist image of the worker, as somehow endowed with an intuitive mastery of science and engineering. Yet, in a sign of the times, Dudintsev received a Lenin prize for the novel the following year.

These two moments bookend what has been called the period of "stagnation" under Leonid Brezhnev, a time of reaction against modernism and of nostalgia for an idealized "village" of 
pre-industrial Russia. The stock positive literary character tended to be a peasant and the author foregrounded how peasants tended their own land and traditional wooden cottages, rather than how they served as workers (agricultural laborers) in some state or collective farm. Had "proletarian literature" outlived its time even before the use-by date of Soviet power? Had the overdone cult of the "proletarian," so identified with Soviet rhetoric, effectively spelled the demise of proletarian literature? Or, was this but a local instance of a more universal trend?

\section{Notes}

I. This can be seen, for instance, in the fact that it sent three very highlyplaced officials to attend the All-Union Conference of Proletarian Writers in April I928. Cf. A. Lunacharskii (I928) "S"ezd VAPPa," Na literaturnom postu (3), pp. 2-3.

2. See Katerina Clark, "Little Heroes and Big Deeds: Literature Responds to the First Five-Year Plan," in Sheila Fitzpatrick, ed. (1978) Cultural Revolution in Russia, I928-I93I. Bloomington, Indiana University Press.

3. See especially Chapter Five, “The Literary Class War: Rethinking Proletarian Literature."

4. E.g. "Partorganizatsiia v bor'be za bol'shevistskuiu istoriiu zavodov," Istoriia zavodov (I933) sbornik 4 (5), pp. 75-79; cf. Iu. Zygostei (I934) "Byli gory vysokoi." Istoriia zavodov, 3 (4), pp. I 20-I 27.

5. I have in mind here, in particular, the ambiguous superior the figure of Badin, the strong Party leader who is also a rapist and enemy of Gleb. In the novel there is a potential mentor figure for Gleb in the local head of the secret police, Chibis, but that relationship is not developed.

6. E.g. Iv. Anisimov ( 5 Feb. I933) “Kniga o pafose novogo stroitel'stva. 'Vremia, vpered.'” Literaturnaia gazeta 6.

\section{References}

Anisimov, Iv. (I933). Kniga o pafose novogo stroitel'stva. 'Vremia, vpered'. Literaturnaia gazeta, no. 6 (February 5). 
Azhaev, V. (1948). Daleko ot Moskvy. Novyi mir, (7), pp. I2-3, 20; (Iо), p. I38.

Bachilo, I. (I959). Predislovie. In: A.M. Gor'kiu $i$ sozdanie istorii fabrik i zavodov; Sbornik dokumentov i materialov v pomoshch' rabotaiūshchim nad istoriě fabrik i zavodov. [Sostaviteli: L. M. Zak, S. S. Zimina]. Moscow: Izdatel'stvo sotsial'no ekonomicheskoi literatury, pp. I I.

Bogdat'eva,E.(I9I 8). "Poeziia zolota i poeziia zheleza," Griadushchee, 3 (June). In: M. D. Steinberg, ed., Proletarian Imagination: Self, Modernity, and the Sacred in Russia, I910-1925. Ithaca and London: Cornell University Press, pp. I93.

Brodskii et al., ed. (1929). Literaturnye manifesty (ot simvolizma $k$ oktiabriu). Sbornik materialov. Moscow: Federatsiia, pp. I3 I.

Denning, M. (1996). The Cultural Front: The Laboring of American Culture in the Twentieth Century. London, New York: Verso.

Dobrenko, E. (1997). The Making of the State Writer: Social and Aesthetic Origins of Soviet Literary Culture. Stanford: Stanford University Press.

Gauzner, G. (I934). Kollektivnaia rabota pisatelei 'Belomorstroi'. Istoriia zavodov, sbornik 3-4, pp. I I I-I I3.

Gladkov, F. (I925). Tsement, Krasnaia nov', (3), p. 53; English version Cement, tr. A. S. Arthur and C. Ashleigh. New York: Frederick Ungar, pp. II 3 .

Gorbachev, G. (I928). Sovremennaia russkaia literatura. Leningrad: Priboi, pp. I42.

Gor'kii, M. (I9II). O pisateliakh-samouchkakh. Sovremennyi mir, 2 (February).

Gor'kii, A. M. (I93 I). Za rabotu!. Pravda, 28 November.

Gor'kii, A. M. (I932). “Uskorit' sozdanie 'Istorii zavodov.' Pis'mo A. M. Gor'kogo k 26 zavodov i fabrik," Pravda I932 (I45) (May 27).

Gor'kii, A. M. and Averbakh, L. (1935). O knige. In: M. Gor'kii and D. Mirskii, eds., Byli gory vysokoi. Rasskazy rabochikh Vysokogorskogo zhelznogo rudnika o staroi i novoi zhizni. Moscow: Gosudarstvennoe izdatel'stvo "Istorii fabrik i zavodov." 
Grossman, V. (1938). Stepan Kol'chugin Part II, God XXII, almanakh chetyrnadtsatyi. Moscow: GIKhL, pp. 97.

Kataev, V. (1932). Vremia, vpered!, Krasnaia nov', (I), p. I6.

Klark, K. (2000). RAPP i institutsializatsiia sovetskogo kul'turnogo polia v I920-kh - nachale I930-kh godov. In: Kh. Giunter and E. Dobrenko, eds., Sotsrealisticheskii kanon. Moscow: Akademicheskii proekt, pp. 209-224.

Libedinskii, I. U. (I922). Nedelia in Nashi dni 2, p. 75.

Libedinskii, I. U. (I924). Temy, kotorye zhdut svoikh avtorov. $\mathrm{Na}$ ((omit literaturnom)) postu, (2-3), pp. I I 8.

Malley, L. (1990). Culture of the Future: The Proletkult Movement in Revolutionary Russia. Berkeley/Los Angeles/Oxford: University of California Press.

Malyshkin, A. (1956). Liudi iz zakholut'ia. In: Sobranie sochinenii v dvukh tomakh, vol. II. Moscow: GIKhL, pp. I25, I26, I34, I39, I 54, 234, 263, 272, 363, 3I 7 .

Mirskii, D. (I935). O rudnike. In: M. Gor'kii and D. Mirskii, eds., Byli gory vysokoi. Rasskazy rabochikh Vysokogorskogo zhelznogo rudnika o staroi i novoi zhizni. Moscow: Gosudarstvennoe izdatel'stvo "Istoriia fabrik i zavodov."

Nishchinskii. (1933). Kak my organizovali rabotu po istorii zavodov. Iz opyta redkollegii izd-va imeni K. Marksa v Leningrade. Iztoriia zavodov, sbornik 4-5, pp. 21 5-220

Oktiabr' (I922). "Pis'mo v redaktsiiu”. Pravda, I2 December I922, pp. 5 .

Proletariat i iskusstvo. (I929). Rezoliutsiia predlozhennaia A. Bogdanovym na Pervoi vserossiiskoi konferentsii proletarskikh kul'turno-prosvetitel'nykh organizatsii. In: N. L.

Rabinovich, I. (I933). O zapisi vospominanii. Istoriia zavodov, sbornik 4-5, pp. 206-208.

Segodnia otkryvaetsia Vsesoiuznyi s"ezd pisateli. (I934). Literaturnaia gazeta. (IO4) (August I7), pp. I.

Sozdadim istoriiu 'Krasnogo Manchestera'. Rezoliutsiia Biuro Ivanovskogo gorkoma $\operatorname{VKP}(\mathrm{b})$. (I933). Istoriia zavodov, sbornik $4-5$, p. 8I. 
Stein, L. and Taft, P. (I97I). Introduction. Workers Speak. Self Portraits. New York: Arno and the New York Times, pp. vii.

Steinberg, M. D. (2002). Proletarian Imagination: Self, Modernity, and the Sacred in Russia, I9IO-I925. Ithaca and London: Cornell University Press, pp. 23.

Volkov, A. (I95I). M. Gor'kii i literaturnoe dvizhenie kontsa XIX i nachala XX veka. Moscow: Sovetskii pisatel', pp. 340. 